\title{
Sustaining ethanol production from lime pretreated water hyacinth biomass using mono and co-cultures of isolated fungal strains with Pichia stipitis
}

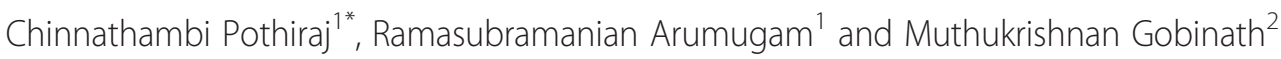

\begin{abstract}
Background: The high rate of propagation and easy availability of water hyacinth has made it a renewable carbon source for biofuel production. The present study was undertaken to screen the feasibility of using water hyacinth's hemicelluloses as a substrate for alcohol production by microbial fermentation using mono and co-cultures of Trichoderma reesei and Fusarium oxysporum with Pichia stipitis.

Results: In separate hydrolysis and fermentation (SHF), the alkali pretreated water hyacinth biomass was saccharified by crude fungal enzymes of T. reesei, F. oxysporum and then fermented by P. stipitis. In simultaneous saccharification and fermentation (SSF), the saccharification and fermentation was carried out simultaneously at optimized conditions using mono and co-cultures of selected fungal strains. Finally, the ethanol production kinetics were analyzed by appropriate methods. The higher crystalline index (66.7\%) and the Fourier transform infrared (FTIR) spectra showed that the lime pretreatment possibly increased the availability of cellulose and hemicelluloses for enzymatic conversion. In SSF, the co-culture fermentation using $T$. reesei and $P$. stipitis was found to be promising with a higher yield of ethanol $\left(0.411 \mathrm{~g} \mathrm{~g}^{-1}\right)$ at $60 \mathrm{~h}$. The additional yield comparable with the monocultures was due to the xylanolytic activity of $P$. stipitis which ferments pentose sugars into ethanol. In SHF, the pretreatment followed by crude enzymatic hydrolysis and fermentation resulted in a significantly lesser yield of ethanol $\left(0.344 \mathrm{~g} \mathrm{~g}^{-1}\right)$ at $96 \mathrm{~h}$.
\end{abstract}

Conclusions: It is evident from the study that the higher ethanol production was attained in a shorter period in the co-culture system containing $T$. reesei and the xylose fermenting yeast $P$. stipitis. SSF of pretreated water hyacinth biomass (WHB) with P. stipitis instead of traditional yeast is found to be an effective biofuel production process.

Keywords: Water hyacinth; Hemicelluloses; Xylose; T. reesei; F. oxysporum; P. stipitis; SSF

\section{Background}

The global depletion of fossil fuels that are the dominant sources for supplying cheap energy for the world's economy has prompted recent significant research efforts in finding viable and sustainable alternatives [1]. Among various options, conversion of abundant lignocellulosic biomass to biofuels has received significant attention. Currently, bioethanol production from corn and sugarcane

\footnotetext{
* Correspondence: pothi2005@yahoo.com

${ }^{1} \mathrm{PG}$ and Research Department of Botany, Alagappa Government Arts College (Alagappa University), Karaikudi, Tamilnadu 630 003, India

Full list of author information is available at the end of the article
}

has posed a threat to the food supply [2], and the cost of these raw materials accounts for up to $40 \%$ to $70 \%$ of the production cost [3]. Lignocellulosic biomass serves as a cheap and abundant feedstock [4], which has the potential to produce low-cost bioethanol at a large scale. In recent days, screening of such substrates for biofuel has gained new speed and still there are many factors to be taken into consideration for the large scale production.

The performance of enzymatic saccharification is one of the foremost limiting factors which may strongly be dependent on the diverse species, complex chemical compositions, and structural characteristics of the feedstock 
materials. The sugar yields from enzymatic hydrolysis vary from plant to plant as a result of the differences mainly in cellulose content [5]. Like cellulose, hemicellulose is also a viable source of fermentable sugars such as xylose for biorefining applications. It was suggested that the production of fuel-grade ethanol from xylose requires a microorganism capable of producing 50 to $60 \mathrm{~g} / \mathrm{L}$ ethanol within $36 \mathrm{~h}$ with a yield of at least $0.4 \mathrm{~g}$ ethanol per gram of sugar [6]. But only few xylose-fermenting microorganisms have been reported earlier [7], and it is generally known that Pichia stipitis is superior to all other yeast species for ethanol production from xylose.

Water hyacinth (Eichhornia crassipes) is a fast growing perennial aquatic weed invasively distributed throughout the world. This tropical plant can cause infestations over large areas of water resources and consequently leads to series of problems like reduction of biodiversity, blockage of rivers and drainage system, depletion of dissolved oxygen, and alteration on water chemistry that leads to severe environmental pollution. In the past, attempts have been geared towards the use of biological, chemical, and mechanical approaches for preventing the spread of, or eradication of, water hyacinth. On the other hand, much attention has been focused on the potentials and constrains of using water hyacinth for a variety of applications since it has a lignocellulosic composition of $48 \%$ hemicelluloses, $18 \%$ cellulose, and $3.5 \%$ lignin $[8,9]$. Since the biomass productivity of this plant is very high, it can be a suitable feedstock for ethanol production.

The technologies for the possible conversion of water hyacinth to biogas or fuel ethanol using fungal extracellular enzymes are well documented in a number of developing countries [10-13]. Saccharomyces cerevisiae and Zymomonas mobilis are being used as candidate organisms in the large-scale production of ethanol from cellulosic biomass. These organisms are capable of utilizing hexose sugars efficiently but not the pentoses, which are the second dominant sugar source in lignocellulosic biomass [14]. From earlier research, $P$. stipitis has been identified as an efficient strain for the conversion of pentose sugars into alcohol [15]. Fermentation technologies utilizing strains of $P$. stipitis instead of traditional yeast have been proposed by a number of authors [14,15], as they have been shown to ferment under fully anaerobic conditions with faster specific rates of pentose sugar uptake and ethanol production as well as an ethanol yield close to theoretical yield. The present study, therefore, was carried out to screen the feasibility of using hexose- and pentose-utilizing fungal strains (Trichoderma reesei, Fusarium oxysporum, and Pichia stipitis) for the effective conversion of water hyacinth biomass into ethanol.

\section{Methods}

\section{Biomass and culture organisms}

Fresh water hyacinth biomass (WHB) was collected from a local pond at Karaikudi, Tamilnadu, India $\left(10.07^{\circ} \mathrm{N}\right.$, $\left.78.78^{\circ} \mathrm{E}\right)$. The collected samples were washed to remove adhering dirt, cut into small piece ( 2 or $3 \mathrm{~mm}$ ) thicknesses, and dried in sunlight. The proximate analysis for biomass was done using standard methods for moisture content, ash, crude protein, crude fibre, cellulose, hemicelluloses, and lignin [16,17]. The fungal strains of $T$. reesei and $F$. oxysporum were isolated by primary selection from a naturally contaminated water hyacinth, and the isolates were confirmed by their morphology and colony characteristics [18]. The isolated organisms were maintained on modified potato dextrose agar (PDA) slants at $4^{\circ} \mathrm{C}$. Fresh colonies were used for saccharification and fermentation studies. The pure culture of $P$. stipitis (NCIM 3497) was procured from the National Collection of Industrial Microorganisms, Pune, India.

\section{Alkaline pretreatment}

The dried WHB $(10 \% w / v)$ was pretreated with calcium hydroxide solution $(0.5 \% \mathrm{w} / \mathrm{v})$ with a soaking time of $3 \mathrm{~h}$ at $100^{\circ} \mathrm{C}$. The pretreated WHB washed to neutrality with distilled water, oven dried to a constant weight, and then milled to powder was used for enzymatic hydrolysis and fermentation [19].

\section{Experimental design}

Two modes of bioconversion methodologies for ethanol production were trialed in the present study. Mode I comprised of a separate hydrolysis and fermentation (SHF) process using crude fungal enzymes with yeast. Mode II was designed to conduct a simultaneous saccharification and fermentation (SSF) process using mono and co-cultures of selected fungal strains.

\section{Separate hydrolysis and fermentation (SHF)}

The cellulolytic enzymes (cellulases and xylanases) were produced by growing the isolated fungal strains of $T$. reesei and $F$. oxysporum separately at $35^{\circ} \mathrm{C}$ in a simple liquid medium $\left(4.2 \mathrm{~g} \mathrm{~L}^{-1}\left(\mathrm{NH}_{4}\right)_{2} \mathrm{SO}_{4}, 2 \mathrm{~g} \mathrm{~L}^{-1} \mathrm{KH}_{2} \mathrm{PO}_{4}\right.$, $0.05 \mathrm{~g} \mathrm{~L}^{-1}$ yeast extract, $2 \mathrm{~mL} \mathrm{~L}^{-1}$ Tween-80, 2\% (w/v) poultry manure with $1.6 \%$ total $\mathrm{N}, \mathrm{pH} 4.8)$ containing $100 \mathrm{~g} \mathrm{~L}^{-1}$ water hyacinth biomass as the chief $\mathrm{C}$ source for 5 days as optimized earlier [20]. The culture supernatants were separated at the end of the incubation period from each organism and used as crude enzymes source for hydrolysis. Cellulase and xylanase activities were measured in the culture supernatant as per standard methods. Cellulase was measured according to the IUPAC methods [21] using Whatman filter paper no. 1 as the substrate and glucose as the standard. Xylanase was assayed by the optimized method described by Bailey 
et al. [22], using 1\% birchwood xylan as the substrate and xylose as the standard. One unit (IU) of enzyme activity is defined as the amount of enzyme releasing $1 \mu \mathrm{mol}$ glucose or xylose/mL per minute

Enzymatic hydrolysis was carried out by incubating the pretreated WHB $(10 \% w / v)$ with the crude fungal enzymes $(10 \%(v / v))$ of $T$. reesei and F. oxysporum separately at $35^{\circ} \mathrm{C}$ for $48 \mathrm{~h}$ with agitation at $200 \mathrm{rpm}$ [23]. The $\mathrm{pH}$ of the reaction mixture (6.0) was maintained at constant. Samples were aliquoted from hydrolysates at a regular interval ( 24 and $48 \mathrm{~h}$ ) to estimate the released sugar content using standard methods [24,25]. The hydrolysates obtained after $48 \mathrm{~h}$ from both the fungal cultures were centrifuged at 10,000 rpm for $10 \mathrm{~min}$. The supernatants were collected separately and supplemented with basal medium ( $1 \mathrm{~g} \mathrm{~L}^{-1}$ yeast extract; $2 \mathrm{~g} \mathrm{~L}^{-1}\left(\mathrm{NH}_{4}\right) \mathrm{SO}_{4}$; $\left.1 \mathrm{~g} \mathrm{~L}^{-1} \mathrm{MgSO}_{4} \cdot 7 \mathrm{H}_{2} \mathrm{O}\right)(\mathrm{pH}$ 6.0) [23]. The culture suspension of P. stipitis $(10 \% v / v)$ was added to initiate the fermentation by incubating the mixture at $35^{\circ} \mathrm{C}$ for $48 \mathrm{~h}$ with agitation at $200 \mathrm{rpm}$.

\section{Simultaneous saccharification and fermentation (SSF)}

SSF represents a single step process in which fermentable sugars get released by enzymatic hydrolysis and are simultaneously exploited by yeasts for fermentation in the same medium. The microbial fermentation was carried out using mono and co-cultures as previously described [9]. The influences of various parameters such as microbial biomass (5\% to $25 \%)$, temperature $\left(25^{\circ} \mathrm{C}\right.$ to $\left.45^{\circ} \mathrm{C}\right)$, and incubation time $(24,36,48,60,72 \mathrm{~h})$ on SSF were also optimized by step-wise experiments where the specified parameters were changed by keeping all other parameters constant. The $\mathrm{pH}$ of the reaction mixture in all the optimization experiments was kept constant at 6.0

\section{Mono and co-culture fermentations}

For monoculture experiments (F1 and F2), previously sterilized $\left(121^{\circ} \mathrm{C}\right.$ for $\left.60 \mathrm{~min}\right)$ pretreated WHB supplemented with a basal medium (without $\mathrm{C}$ source) was inoculated with late log-phase cultures of $T$. reesei (F1) and F. oxysporum (F2), separately. For co-culture fermentation (F3 and F4), separate sets of reaction mixtures consisting of pretreated WHB supplemented with basal medium were treated with $P$. stipitis simultaneously with T. reesei (F3) and F. oxysporum (F4). The fermentation process was carried out at optimized conditions.

\section{Estimations}

Samples were withdrawn from the fermenting media at regular intervals of time for the determination of ethanol, residual sugar concentration, and microbial biomass. Estimation of xylose was done by the Trinder method [24] and glucose by the DNS method [25]. Ethanol estimation was done spectrophotometrically by potassium dichromate method [26]. The microbial biomass was determined by harvesting cells by centrifugation, drying them at $70^{\circ} \mathrm{C}$ under vacuum to a constant weight, and expressed as gram dry cell weight (DCW) per liter [27]. The kinetic parameters of ethanol fermentation were determined followed by Abate et al. [28] as follows:

$$
\begin{aligned}
\text { Ethanol concentration }(E \mathrm{c})=\begin{array}{l}
\text { [ethanol produced }(\mathrm{g}) / \\
\text { volume of reaction mixture }(\mathrm{L})]
\end{array} \\
\text { Ethanol productivity }\left(E_{\mathrm{p}}\right)=\begin{array}{l}
{[\text { ethanol produced }(\mathrm{g}) /} \\
\text { volume of reaction mixture }(\mathrm{L}) / \\
\text { time }(\mathrm{h})]
\end{array} \\
\text { Ethanol Yield }\left(E_{\mathrm{y}}\right)=\begin{array}{l}
{[\text { ethanol produced }(\mathrm{g}) /} \\
\text { weight of substrate }(\mathrm{g})]
\end{array} \\
\text { Specific ethanol yield }\left(E_{\mathrm{sy}}\right)=\begin{array}{l}
\text { ethanol produced }(\mathrm{g}) / \\
\text { sugar consumed }(\mathrm{g})]
\end{array}
\end{aligned}
$$

The results obtained were analyzed by using analysis of variance (ANOVA), and the group means were compared with Duncan's Multiple Range Test (DMRT) [29].

\section{Fourier transform infrared (FTIR) analysis}

Fourier transform infrared spectra were studied on treated and untreated WHB using a Shimadzu spectrometer (Shimadzu, Kyoto, Japan). For this, $3.0 \mathrm{mg}$ of the sample was dispersed in $300 \mathrm{mg}$ of spectroscopic grade $\mathrm{KBr}$ and subsequently pressed into disks at $10 \mathrm{MPa}$ for $3 \mathrm{~min}$. The spectra were obtained with an average of 25 scans and a resolution of $4 \mathrm{~cm}^{-1}$ in the range of 4,000 to $400 \mathrm{~cm}^{-1}$.

\section{X-ray diffraction (XRD) analysis}

The crystallinity of cellulose in the pretreated and treated water hyacinth was analyzed by X-ray diffraction method in a PANalytical X'pert ${ }^{3}$ PRO Diffractometer (PANalytical B.V., Almelo, Netherlands) set at $40 \mathrm{KV}$, $30 \mathrm{~mA}$; radiation was $\mathrm{Cu} K \alpha(\lambda=1.54 \hat{A})$ and the grade range between 10 to $30^{\circ}$ with a step size of $0.03^{\circ}$. The crystallinity index ( $\mathrm{CrI})$ was determined based on the equation shown below [30]:

$$
\mathrm{CrI}=\frac{I_{002}-I_{\mathrm{am}}}{I_{\mathrm{am}}} \times 100
$$

where $I_{002}$ is the intensity of the diffraction from the 002 plane at $2 \theta=22.6^{\circ}$ and $I_{\mathrm{am}}$ is the intensity of the background scatter measured at $2 \theta=18.7^{\circ}$. It is known that the $I_{002}$ peak corresponds to the crystalline fraction and the $I_{\mathrm{am}}$ peak corresponds to the amorphous fraction [31].

\section{Results and discussion}

The lignocellulosic biomass composition of WH includes cellulose (20.2 g $100 \mathrm{~g}^{-1}$ dry matter (DM)), hemicellulose (34.3 g $\left.100 \mathrm{~g}^{-1} \mathrm{DM}\right)$, lignin (4.4 g $100 \mathrm{~g}^{-1} \mathrm{DM}$ ), crude

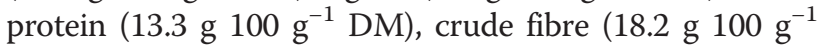


Table 1 Proximate composition of water hyacinth biomass (WHB) comparable with earlier literatures

\begin{tabular}{|c|c|c|c|c|}
\hline \multirow[t]{2}{*}{ Content } & \multirow{2}{*}{$\begin{array}{l}\text { Present study } \\
\left.\text { [g } 100 \mathrm{~g}^{-1} \mathrm{DM}\right]\end{array}$} & \multicolumn{3}{|c|}{ Previous literature } \\
\hline & & [g $\left.100 \mathrm{~g}^{-1} \mathrm{DM}\right]$ [8] & [g $\left.100 \mathrm{~g}^{-1} \mathrm{DM}\right]$ [12] & [g $\left.100 \mathrm{~g}^{-1} \mathrm{DM}\right][32]$ \\
\hline Moisture (\%) & 92.8 & - & - & - \\
\hline Ash & 15.4 & 20.0 & - & 20.0 \\
\hline Crude protein & 13.3 & 18.0 & 10.2 & 18.0 \\
\hline Crude fibre & 18.2 & - & - & - \\
\hline Cellulose & 20.2 & 25.0 & 19.02 & 25.0 \\
\hline Hemicellulose & 34.3 & 35.0 & 32.69 & 35.0 \\
\hline Lignin & 4.4 & 10.0 & 4.37 & 10.0 \\
\hline
\end{tabular}

DM, dry matter.

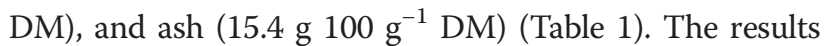
obtained in the present study on the proximate composition of WHB are basically consistent with previous literatures $[8,12,32]$. The digestibility of lignocelluloses is hindered by many physicochemical, structural, and compositional factors which required a suitable pretreatment in order to enhance the susceptibility of biomass for hydrolysis. It is highly essential for the economical production of ethanol that both the cellulose and hemicellulosic sugars present in the biomass should be utilized efficiently. The FTIR and XRD data in the present study clearly suggested that the pretreatment with lime could increase the availability of polysaccharide for enzymatic hydrolysis. Among different pretreatment methods used in earlier researches for water hyacinth, maximum reducing sugar was observed in diluted $\mathrm{H}_{2} \mathrm{SO}_{4}\left(0.342 \mathrm{~g} \mathrm{~g}^{-1}\right.$ biomass) [33], $\mathrm{HCl}$ (0.277 $\mathrm{g} \mathrm{g}^{-1}$ biomass), acetic acid (0.097 $\mathrm{g} \mathrm{g}^{-1}$ biomass), and formic acid $\left(0.088 \mathrm{~g} \mathrm{~g}^{-1}\right.$ biomass) [31,34]. In comparison with the above reports, it is evident that the lime pretreatment used in the present study is a promising method for higher sugar yield. The pretreatment with $\mathrm{Ca}$ $(\mathrm{OH})_{2}$ is preferable because it is less expensive, more safe as compared to $\mathrm{NaOH}$, and it can be easily recovered from the hydrolysate by reaction with $\mathrm{CO}_{2}$. Lime has been used to pretreat many lignocellulosic materials such as wheat straw [35], poplar wood [36], and corn stover [37].

\section{XRD - cellulose crystallinity}

Cellulose crystallinity, usually measured as CrI, is considered an important parameter determining the enzymatic hydrolysis susceptibility of cellulose. The CrI of a cellulose sample is an indication of the degree of formed crystallinity in the sample when the cellulose aggregates. The crystallinity has been found to have a greater impact on enzymatic hydrolysis than other structural characteristics such as the degree of polymerization (DP) of cellulose or the specific surface area (SSA) [38]. The XRD profile of WHB indicated that the CrI of untreated WHB is $28.6 \%$ and alkali-treated WHB is $66.7 \%$ (Figure 1). The X-ray diffractogram clearly revealed that the lime pretreatment increased the crystallinity of cellulose in water hyacinth. Similar results were reported earlier by Kim and Holtzapple [39] who found that the degree of crystallinity of corn stover slightly increased from $43 \%$ to $60 \%$ through delignification with calcium hydroxide and by $\mathrm{Li}$ et al. [40] who have reported high cellulose CrI of $70.6 \%$ in Metasequoia chips by nitric acid-ethanol method. The increase in CrI of alkali-treated WHB might be due to the removal of amorphous components including lignin during the pretreatment process [41,42]. According to Satyanagalakshmi et al. [33], the amorphous cellulose portions in aquatic plants are more prone to recrystallization to form crystalline cellulose, resulting in greater increases in CrI.

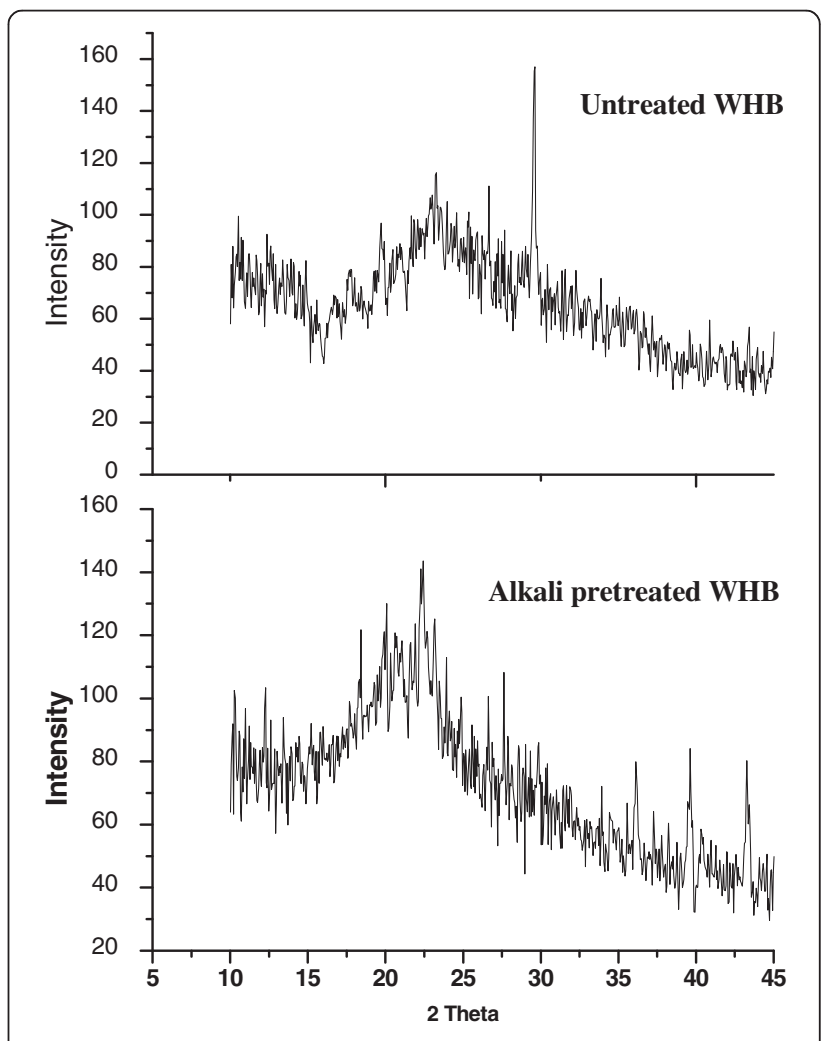

Figure 1 XRD analysis of untreated and lime pretreated WHB. 


\section{FTIR analysis}

FTIR spectra of the untreated and treated samples indicated structural changes in the biomass upon pretreatment (Figure 2). The increased absorption bands at 1,000 to $1,200 \mathrm{~cm}^{-1}$ were related to structural features of cellulose and hemicelluloses [43]. The spectra of alkalitreated WHB sample (Figure 3) showed increase in absorbance in the above-mentioned range. The peak at $1,635 \mathrm{~cm}^{-1}$ was observed due to either the acetyl and uronic ester linkage of carboxylic group of the ferulic and p-coumeric acids of lignin and/or hemicelluloses [44]. A sharp band at $896 \mathrm{~cm}^{-1}$, corresponding to the $\mathrm{C} 1$ group frequency or ring frequency, was attributed to the glycosidic linkages between xylose units in hemicelluloses [45]. The peaks in the pretreated sample had the highest absorbance suggesting increase in cellulose and hemicellulose content. In the FTIR spectrum, the peaks observed at 1,092 and $842 \mathrm{~cm}^{-1}$ were attributed to $\mathrm{C}-\mathrm{O}$ stretching and $\mathrm{C}-\mathrm{H}$ rocking vibration of the cellulose structure.

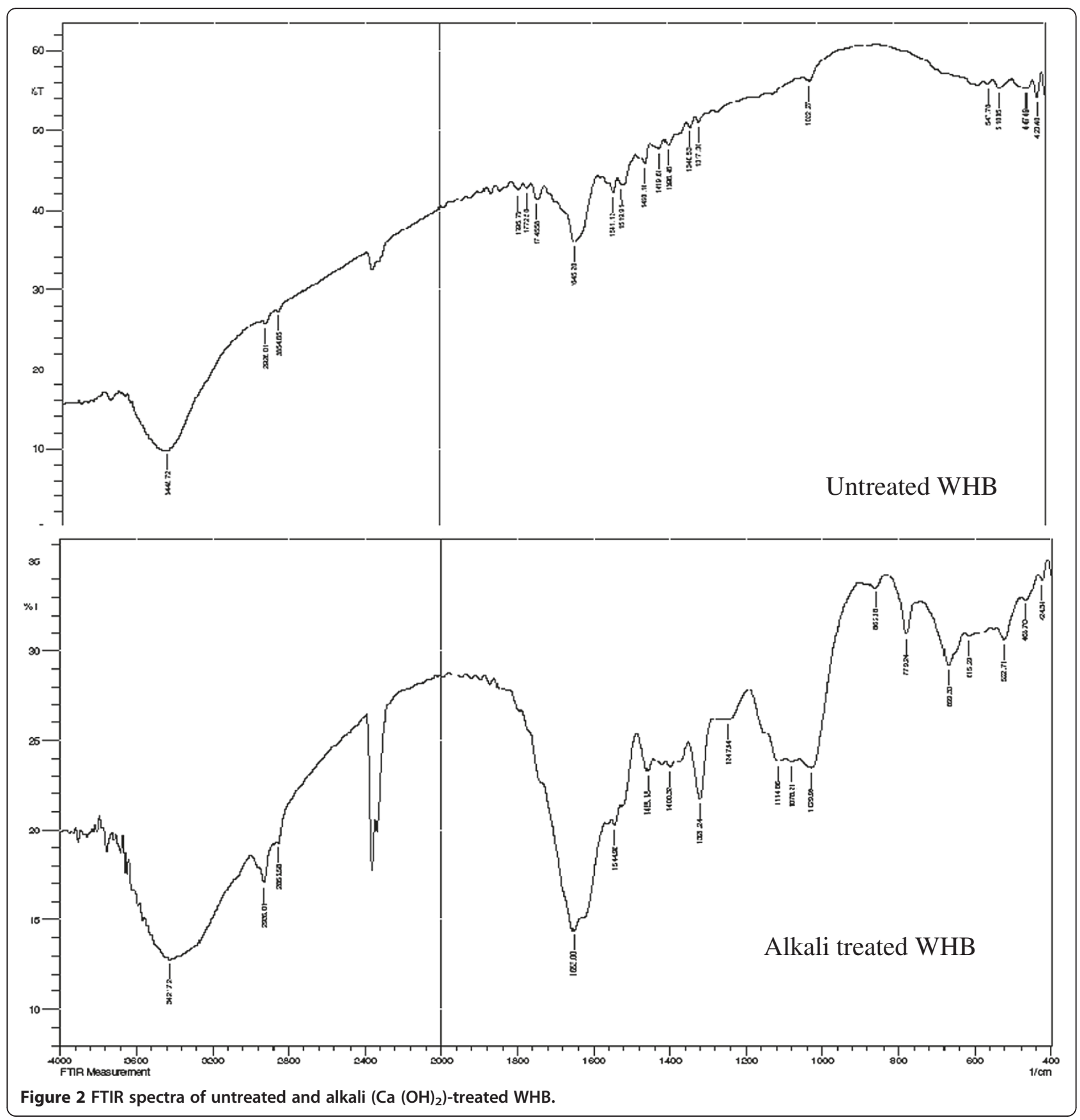




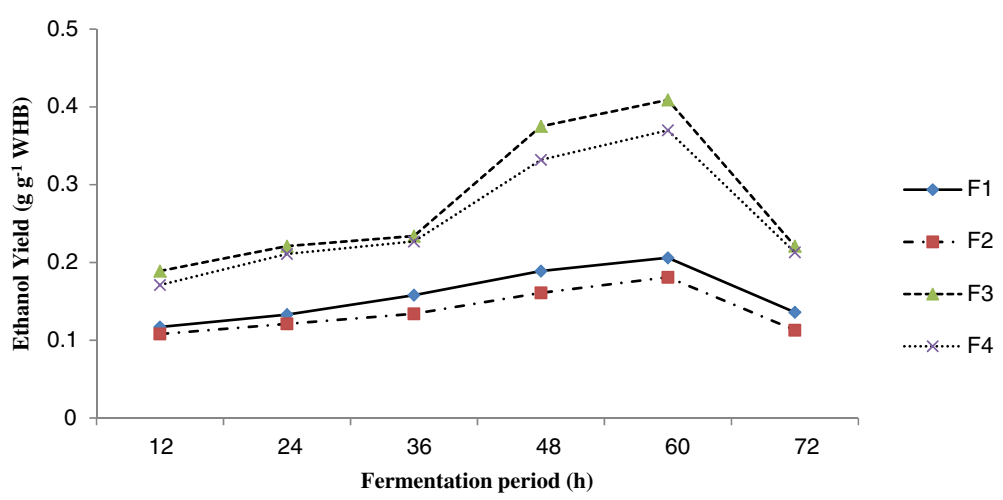

Figure 3 Effect of fermentation period on ethanol yield from pretreated WHB using mono and co-cultures. F1, T. reesei; F2, F. oxysporum; F3, T. reesei + P. stipitis; F4, F. oxysporum + P. stipitis.

\section{Enzyme activity}

In recent decades, the use of fungi in bioprocesses has grown in importance because of the production of numerous enzymes with different biochemical properties and excellent potential for biotechnological application. The cellulase and xylanase activities reached their maximum values on the 6th day of incubation for both the fungal isolates. Cellulase production on WHB with nutrient supplements indicated higher cellulase production by $T$. reesei $(0.923 \mathrm{IU} / \mathrm{mL})$ compared to $F$. oxysporum $(0.432 \mathrm{IU} / \mathrm{mL})$. However, it is less than the value of $1.35 \mathrm{IU} / \mathrm{mL}$ reported by Deshpande et al. [46] on the substrate water hyacinth with Toyama-Ogawa medium [47]. The xylanase production was slight, but significantly higher in $F$. oxysporum (0.764 IU/mL), compared to $T$. reesei $(0.611 \mathrm{IU} / \mathrm{mL})$. According to Kang et al. [48], high xylanase production in some fungi has been shown to be linked strictly to the ratio of cellulose to xylan of the growth substrate and substrate degradation due to time course or incubation period.

According to Polizeli et al. [49], filamentous fungi are widely utilized as enzyme producers and are generally considered more potent xylanase producers than bacteria or yeast. Several mesophilic fungal species have been evaluated in relation to xylanase production, including members of Aspergillus, Trichoderma, and Penicillium. Currently, most commercial xylanolytic preparations are produced by genetically modified Trichoderma or Aspergillus strains [50].

\section{Sugar yield}

The yield of sugars from enzymatic hydrolysis of WHB using crude enzymes produced by fungal isolates was summarized in Table 2. The saccharification was significantly higher $(40.8 \%)$ while using crude enzyme from $T$. reesei when compared to $F$. oxysporum (38.2\%). The release of total sugars by the crude enzymes of both monocultures increased slowly to reach a peak value at $48 \mathrm{~h}$ of incubation. The maximum yield of total sugar $\left(0.531 \mathrm{~g} \mathrm{~g}^{-1} \mathrm{WHB}\right)$ including glucose $\left(0.444 \mathrm{~g} \mathrm{~g}^{-1} \mathrm{WHB}\right)$ and xylose $\left(0.057 \mathrm{~g} \mathrm{~g}^{-1}\right.$ WHB) was observed after $48 \mathrm{~h}$ of hydrolysis using crude enzymes of $T$. reesei. The crude enzymes obtained from $F$. oxysporum produced comparably lower reducing sugar (0.428 $\mathrm{g} \mathrm{g}^{-1}$ WHB) and xylose (0.038 $\left.\mathrm{g} \mathrm{g}^{-1} \mathrm{WHB}\right)$. Thus, it substantiates that the amount of sugar released increases with time which may be due to the increased action of cellulolytic and xylanolytic enzymes of $T$. reesei and $F$. oxysporum [51]. The cellulolytic fungus $T$. reesei looks promising for on-site cellulase production due to its superior features, i.e., capability to produce all components of cellulase complex, endocellulase, exocellulase, and $\beta$ glucosidase in good proportions as well as production of other enzymes such as xylanases or laccases in comparison to other enzyme producers [52].

\section{Ethanol}

The optimization studies in SSF showed that the yield of ethanol is found to be proportional to fermentation time where the yield increases with the increase in time up to $60 \mathrm{~h}$ and then declines (Figure 3). Maximum yield of

Table 2 Sugar composition ( $\mathrm{g} \mathrm{g}^{-1}$ WHB) of enzymatic hydrolysates of pretreated WHB at $48 \mathrm{~h}$

\begin{tabular}{lccc}
\hline Enzyme source & Glucose & Xylose & Total sugar \\
\hline T. reesei & $0.444^{\mathrm{a}} \pm 0.12$ & $0.057^{\mathrm{a}} \pm 0.09$ & $0.531^{\mathrm{a}} \pm 0.12$ \\
F. oxysporum & $0.428^{\mathrm{b}} \pm 0.31$ & $0.038^{\mathrm{b}} \pm 0.11$ & $0.488^{\mathrm{b}} \pm 0.17$ \\
\hline
\end{tabular}

Values are the mean of three replicates \pm SE. Means followed by the same letter within treatment do not differ significantly $(p=0.05)$. 


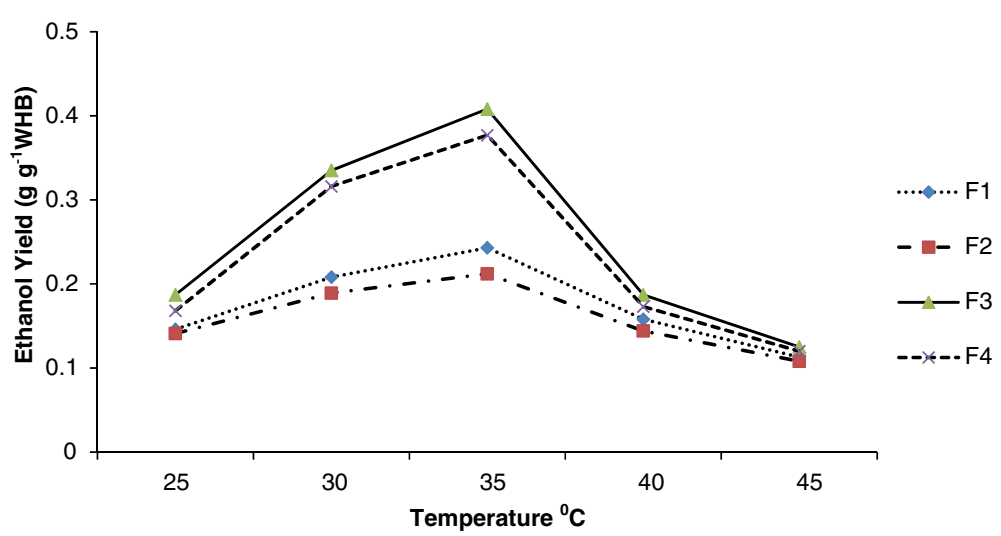

Figure 4 Effect of temperature on ethanol yield from pretreated WHB using mono and co-cultures. F1, T. reesei; F2 F. oxysporum; F3 T. reesei + P. stipitis; F4, F. oxysporum + P. stipitis.

ethanol is $0.413,0.378,0.194$, and $0.187 \mathrm{~g} \mathrm{~g}^{-1}$ of WHB at $60 \mathrm{~h}$ of fermentation for F3, F4, F1, and F2, respectively. After $60 \mathrm{~h}$ of time, the yield of ethanol decreases in all treatments, and therefore, fermentation time of $60 \mathrm{~h}$ is taken as the optimum time for ethanol fermentation. With the increase in temperature, the yield of ethanol increased up to $35^{\circ} \mathrm{C}$ and then it decreased (Figure 4). At high temperature $\left(>35^{\circ} \mathrm{C}\right)$, death rate exceeds the growth rate, which causes a net decrease in concentration of viable fungal populations with lower generation of ethanol. With the increase in loading of biomass, the yield of ethanol increased up to $10 \%$ and then decreased in all the samples (Figure 5). The decrease in ethanol yield with the increase in biomass loading can be attributed to the inhibitory effect of either the product or the biomass. Inhibitory compounds limit efficient utilization of hydrolysates by the fermenting organism resulting in less ethanol production [33].

In the SHF process, a maximum of $14.3 \mathrm{~g} \mathrm{~L}^{-1}$ ethanol was produced at the end of the process $(96 \mathrm{~h}$ ) which is equivalent to $0.143 \mathrm{~g} \mathrm{~g}^{-1}$ WHB (Table 3). The minimum production of ethanol observed in the submerged fermentation of pretreated water hyacinth biomass using monocultures of $T$. reesei and $F$. oxysporum was due to the inability of these organisms to convert pentose sugars into ethanol. A similar finding was reported earlier where $0.11 \mathrm{~g}$ ethanol was obtained from alkalipretreated water hyacinth through SHF [23]. According to Preez et al. [53] P. stipitis is known to produce ethanol up to 33 to $57 \mathrm{~g} / \mathrm{L}$; however, $30 \mathrm{~g} / \mathrm{L}$ is known as a critical concentration above which cells cannot grow at $30^{\circ} \mathrm{C}$.

In SSF, monocultures of T. reesei (F1) and F. oxysporum (F2) produced 19.3 and $17.8 \mathrm{~g} \mathrm{~L}^{-1}$ ethanol, respectively, after 60-h fermentation (Table 4). Simultaneous coculturing of T. reesei (F3) and F. oxysporum (F4) with $P$. stipitis resulted in a higher ethanol production (40.8 and $36.8 \mathrm{~g} \mathrm{~L}^{-1}$, respectively) at the same time. The maximal ethanol yield was $0.411 \mathrm{~g} \mathrm{~g}^{-1}$ WHB when P. stipitis was used along with $T$. reese $i$ which is positively correlated to the theoretical yield $0.429 \mathrm{~g}$ on the basis of biomass. Since xylose was present as a predominant sugar in the WHB hydrolysate, $P$. stipitis was used to make the biomass-toethanol process more economical. Mishima et al. [34], on

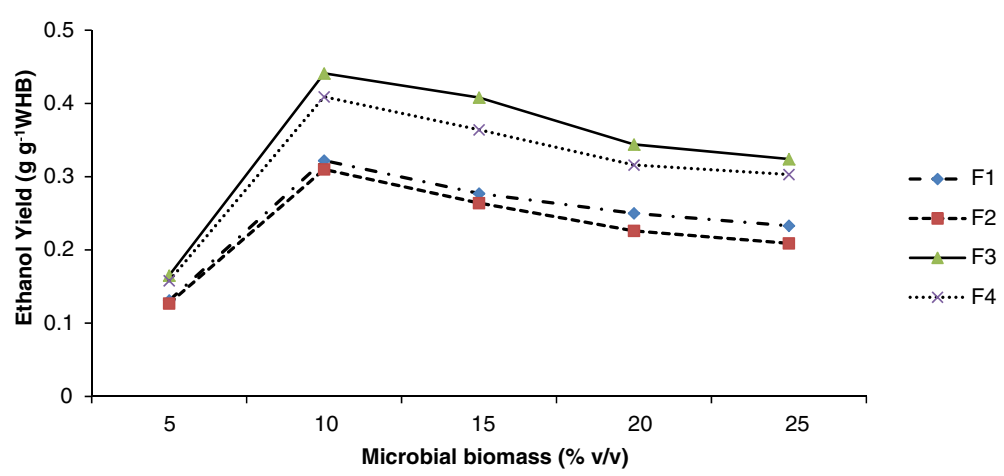

Figure 5 Effect of microbial biomass on ethanol yield from pretreated WHB using mono and co-cultures. F1, T. reesel; F2, F. oxysporum; F3, T. reesei + P. stipitis; F4, F. oxysporum + P. stipitis. 
Table 3 Ethanol production in SHF process using crude fungal enzymes and $P$. stipitis with pretreated WHB at $96 \mathrm{~h}$

\begin{tabular}{|c|c|c|c|c|c|}
\hline Sample (s) & $E_{c}$ & $E_{p}$ & $E_{y}$ & $E_{s y}$ & $\mathrm{E}_{\mathrm{TE}}$ \\
\hline$S_{1}$ & $14.3^{c} \pm 0.12$ & $0.24^{a} \pm 0.09$ & $0.143^{c} \pm 0.11$ & $0.322^{c} \pm 0.11$ & $0.261^{c} \pm 0.11$ \\
\hline $\mathrm{S}_{2}$ & $12.8^{d} \pm 0.13$ & $0.21^{a} \pm 0.17$ & $0.128^{d} \pm 0.08$ & $0.299^{d} \pm 0.08$ & $0.243^{d} \pm 0.17$ \\
\hline
\end{tabular}

the other hand, reported a lesser ethanol yield of 0.14 $\mathrm{g} \mathrm{g}^{-1}$ dry substrate through SSF of pretreated water hyacinth using commercial cellulase and S. cerevisiae. The overall production could be enhanced by co-culture rather than monoculture of test organisms. Similarly, direct microbial conversion of cellulosic or lignocellulosic biomass into ethanol using co-cultures had been reported by several authors [32,34,54]. S. cerevisiae or Z. mobilis utilize glucose or sucrose efficiently but their inability to utilize pentose sugars make them inappropriate candidates for refineries, but the candidate organism $P$. stipitis used in the present study showed efficient conversion of pentose sugars into alcohol. Among the pentose-fermenting organisms, $P$. stipitis has been shown to have the most promise for industrial applications [55]. Earlier reports showed that the hemicellulosic hydrolysates of Prosopis juliflora (18.24 g sugar/L broth) when fermented with P. stipitis produced $7.13 \mathrm{~g} / \mathrm{L}$ ethanol [56]. Kuhad et al. [57] observed $0.33 \mathrm{~g} \mathrm{~g}^{-1}$ ethanol yield from detoxified xylose-rich hydrolysate of Lantana camara fermented with $P$. stipitis at pH 5 for 36 h. Similarly, the detoxified water hyacinth hemicellulose acid hydrolysate (rich in pentose sugars) fermented with $P$. stipitis NCIM-3497 at pH 6.0 and $30^{\circ} \mathrm{C}$ resulted in $0.425 \mathrm{~g}$ ethanol/g lignocelluloses [15]. The yield of ethanol per unit biomass of water hyacinth obtained through the bioprocess in the present study was comparable to or even better than those reported earlier. The current results clearly demonstrated the saccharification potential of $T$. reesei and F. oxysporum, where the performance of both strains in co-cultures with $P$. stipitis was significantly higher than their respective single culture.

\section{Microbial biomass}

All the co-culture processes reached a higher value of microbial biomass than the single fermentation process. A maximum of $3.12 \mathrm{~g} \mathrm{DCW} \mathrm{L}^{-1}$ biomass content was obtained in the co-culture of $T$. reesei and P. stipitis at 60-h fermentation (Table 4). Inoculation of $P$. stipitis with $F$. oxysporum resulted in a biomass content of $2.64 \mathrm{~g} \mathrm{DCW} \mathrm{L}^{-1}$ over the monocultures. Statistically, a less significant difference was observed with monoculture's fermentation when compared with co-culture [58].

\section{Conclusions}

The fermentation of bioethanol from pretreated water hyacinth biomass with mono and co-cultures of fungal strains along with $P$. stipitis is found to be an effective biofuel production process. The yield of ethanol recovered from WHB through enzymatic hydrolysis and fermentation from simultaneous inoculation of co-cultures of fungal isolates with $P$. stipitis was significantly higher than that recovered through monocultures. The optimum parameters for bioethanol fermentation are as follows: time $60 \mathrm{~h}$, temperature $35^{\circ} \mathrm{C}$, and $\mathrm{WHB}$ loading $100 \mathrm{~g} \mathrm{~L}^{-1}$. The maximum yield of ethanol in the fermentation process was found to be $0.411 \mathrm{~g} \mathrm{~g}^{-1}$ of WHB which is equivalent to a specific yield of $0.456 \mathrm{~g} \mathrm{~g}^{-1}$ total sugar consumed. The use of crude fungal enzymes produced on-site would be a cost-effective approach towards enzymatic hydrolysis of alkali-pretreated WHB biomass instead of using commercial cellulases. The aquatic menace water hyacinth, which is currently being used in waste water treatment for its unique ability to absorb heavy metal pollutants, could also be utilized as abundant cheap feedstock for the production of fuel ethanol. This study proved that water hyacinth has a potential renewable and low-cost biomass for alcohol production on the commercial scale. Present cost effectiveness of respective process at a commercial scale needs to be standardized, and the water hyacinth biomass could be a better substrate source for alcohol production.

Table 4 Ethanol production in mono and co-culture fermentation process (SSF) using pretreated WHB at $60 \mathrm{~h}$

\begin{tabular}{|c|c|c|c|c|c|}
\hline Culture $(s)$ & $E_{c}$ & $E_{p}$ & $\mathrm{E}_{\mathrm{y}}$ & $E_{s y}$ & Microbial biomass $\left(\mathrm{g} \mathrm{DCW} \mathrm{L}^{-1}\right)$ \\
\hline T. reesei & $19.3^{c} \pm 0.12$ & $0.32^{c} \pm 0.09$ & $0.196^{c} \pm 0.11$ & $0.377^{c} \pm 0.11$ & $2.14^{\complement} \pm 0.01$ \\
\hline F. oxysporum & $17.8^{d} \pm 0.13$ & $0.29^{d} \pm 0.17$ & $0.176^{d} \pm 0.08$ & $0.348^{d} \pm 0.08$ & $2.06^{c} \pm 0.08$ \\
\hline T. reesei + P. stipitis & $40.8^{a} \pm 0.09$ & $0.68^{\mathrm{a}} \pm 0.14$ & $0.411^{\mathrm{a}} \pm 0.03$ & $0.798^{\mathrm{a}} \pm 0.11$ & $3.12^{\mathrm{a}} \pm 0.12$ \\
\hline F. oxysporum + P. stipitis & $36.8^{\mathrm{b}} \pm 0.06$ & $0.61^{b} \pm 0.12$ & $0.371^{b} \pm 0.07$ & $0.720^{\mathrm{b}} \pm 0.08$ & $2.64^{b} \pm 0.20$ \\
\hline
\end{tabular}

$E_{c}$, ethanol concentration $\left(\mathrm{g} \mathrm{L}^{-1}\right) ; \mathrm{E}_{\mathrm{p}}$, ethanol productivity $\left(\mathrm{g} \mathrm{L}^{-1} \mathrm{~h}^{-1}\right) ; \mathrm{E}_{\mathrm{y}}$, ethanol yield $\left(\mathrm{g} \mathrm{g}^{-1}\right.$ WHB); $\mathrm{E}_{\mathrm{sy}}$, specific ethanol yield $\left(\mathrm{g} \mathrm{g}^{-1}\right.$ sugar). Values are the mean of three replicates \pm SE. Mean followed by the same letter within treatment do not differ significantly $(p=0.05)$. 


\section{Competing interests}

The authors declare that they have no competing interests.

\section{Authors' contributions}

CP carried out the submerged fermentation processes and helped design the whole study. RA carried out proximate analysis of biomass and helped in manuscript preparation. RMG helped in characterization of biomass using FTIR and XRD. All authors read and approved the final manuscript.

\section{Acknowledgements}

The authors are thankful to all faculty members of the PG and Research Department of Botany, Alagappa Government Arts College (Alagappa University), Karaikudi. We also acknowledge the Head, Department of physics, Alagappa University, Karaikudi and the Department of Chemistry, VHNSN College, Virudhunagar, Tamilnadu for helping us with XRD and FTIR analysis, respectively.

\section{Author details}

${ }^{1}$ PG and Research Department of Botany, Alagappa Government Arts College (Alagappa University), Karaikudi, Tamilnadu 630 003, India. ${ }^{2}$ Department of Microbiology, VHNSN College, Virudhunagar, Tamilnadu 626 001, India.

Received: 30 July 2014 Accepted: 10 November 2014

Published online: 06 December 2014

\section{References}

1. Chang KL, Thitikorn-amorn J, Hsieh JF, Ou BM, Chen SH, Ratanakhanokchai K, Huang PJ, Chen ST (2011) Enhanced enzymatic conversion with freeze pretreatment of rice straw. Biomass Bioenergy 35(1):90-95

2. Guragain YN, De Coninck J, Husson F, Durand A, Rakshit SK (2011) Comparison of some new pretreatment methods for second generation bioethanol production from wheat straw and water hyacinth. Bioresour Technol 102(6):4416-4424

3. Quintero JA, Montoya MI, Sánchez OJ, Giraldo OH, Cardona CA (2008) Fuel ethanol production from sugarcane and corn: comparative analysis for a Colombian case. Energy 33(3):385-399

4. Balat M (2011) Production of bioethanol from lignocellulosic materials via the biochemical pathway: a review. Energy Convers Manage 52(2):858-875

5. Sukumaran RK, Singhania RR, Mathew GM, Pandey A (2009) Cellulase production using biomass feed stock and its application in lignocelluloses saccharification for bio-ethanol production. Renew Energy 34(2):421-424

6. Lee Y, Kim M, Kim K, Park K, Ryu Y, Seo J (2000) A parametric study on ethanol production from xylose Pichia stipitis. Biotechnol Bioprocess Eng 5:27-31

7. Ganguly A, Das S, Bhattaacharya A, Dey A, Chatterjee PK (2013) Enzymatic hydrolysis of water hyacinth biomass for the production of ethanol: optimization of driving parameters. Ind J Exp Biol 51:556-566

8. Gunnarsson CC, Petersen CM (2007) Water hyacinth as a resource in agriculture and energy production: a literature review. Waste Man 27:117-129

9. Nigam JN (2002) Bioconversion of water hyacinth (Eichhornia crassipes) hemicellulose acid hydrolysate to motor fuel ethanol by xylose-fermenting yeast. J Biotech 97:107-116

10. Zabala I, Ferrer A, Ledesma A, Aiello C (1994) Microbial protein production by submerged fermentation of mixed cellulolytic cultures In: Galindo E, Ramirez OT (eds) Advances in Bioprocess Engineering. Kluwer Academic Publishers, The Netherlands, pp 455-460

11. Singhal V, Rai JP (2003) Biogas production from water hyacinth and channel grass used for phytoremediation of industrial effluents. Bioresour Technol $86: 221-225$

12. Sornvoraweat B, Kongkiattikajorn J (2010) Separated hydrolysis and fermentation of water hyacinth leaves for ethanol production. KKU Res J 15(9):794-802

13. Idrees M, Adman A, Sheikh S, Qureshi FA (2013) Optimization of dilute acid pretreatment of water hyacinth biomass for enzymatic hydrolysis and ethanol production. EXCLI J 12:30-40

14. Bhattacharya A, Ganguly A, Das S, Chatterjee PK, Dey A (2013) Fungal isolates from local environment: isolation, screening and application for the production of ethanol from water hyacinth. Int J Emerg Tech Adv Engi 3(3):58-65
15. Kumari N, Bhattacharya A, Dey A, Ganguly A, Chatterjee PK (2014) Bioethanol production from water hyacinth biomass using isolated fungal strain from local environment. Biolife 2(2):516-522

16. Association of Official Analytical Chemists (AOAC) (1975) Methods of analysis of the Association of Official Analytical Chemists. Association of Official Analytical Chemists, Washington DC

17. Robertson JB, van Soest PJ (1981) The Detergent System of Analysis and its application to human foods. In: James WPT, Thiander O (eds) The analysis of dietary fibers in food. Marcel Dekker, New York, pp 123-158

18. Alexopoulos CJ, Beneke ES (1962) Laboratory manual for introductory mycology. 1, 2 Burgess publishing Co, Minneapolis

19. Chang VS, Burr B, Holtzapple MT (1997) Lime pretreatment of switchgrass. Appl Biochem Biotechnol 63(65):3-19

20. Mukhopadhyay S, Nandi B (2001) Cellulase production by Trichoderma reesei on pretreated water hyacinth: effect of nutrients. J Mycopathol Res 39(1):57-60

21. Ghose TK (1987) Measurement of cellulose activities. Pure Applied Chem 59(257):268

22. Bailey M, Buchert J, Viikari L (1993) Effect of $\mathrm{pH}$ on production of xylanase of Trichoderma reesei on xylan- and cellulose-based media. Appl Microbiol Biotechnol 40:224-229

23. Mukhopadhyay S, Mukherjee PS, Chatterjee NC (2008) Optimization of enzymatic hydrolysis of water hyacinth by Trichoderma reesei vis-à-vis production of fermentable sugars. Acta Aliment 37(3):367-377

24. Trinder $P$ (1975) Micro-determination of xylose in plasma. Analyst 100:12-15

25. Miller GL (1959) Use of DNS reagent for the determination of reducing sugars. Anal Chem 31:426-428

26. Caputi A, Veda M, Brown T (1968) Spectrophotometric determination of ethanol in wine. American J Enol Viticul 19:160-165

27. Doelle HW, Greenfield PF (1985) The production of ethanol from sucrose using Zymomonas mobilis. Appl Microbial Biotechnol 22:405-441

28. Abate C, Callieri D, Rodriguez E, Garro O (1996) Ethanol production by mixed culture of flocculent strains of Zymomonas mobilis and Saccharomyces sp. Appl Microbial Biotechnol 45:580-583

29. Duncan BD (1957) Multiple range tests for correlated and heteroscedastic means. Biometrics 13(2):359-364

30. Segal L, Creely JJ, Martin AE, Conrad CM (1959) An empirical method for estimating the degree of crystallinity of native cellulose using $X$-Ray diffractometer. Text Res J 29:786-794

31. Wang LS, Zhang YZ, Gao PJ, Shi DX, Liu HW, Gao HJ (2006) Changes in the structural properties and rate of hydrolysis of cotton fibers during extended enzymatic hydrolysis. Biotechnol Bioeng 93(3):443-456

32. Aswathy US, Sukumaran RK, Lalitha Devi G, Rajasree KP, Singhania RR, Pandey A (2010) Bio-ethanol from water hyacinth biomass: an evaluation of enzymatic saccharification strategy. Biores Technol 101:925-930

33. Satyanagalakshmi K, Sindhu R, Binod P, Janu KU, Sukumaran RK, Pandey A (2011) Bioethanol production from acid pretreated water hyacinth by separate hydrolysis and fermentation. J Sci Ind Res 70:156-161

34. Mishima D, Kuniki M, Sei K, Soda S, Ike M, Fujita M (2008) Ethanol production from candidate energy crops: water hyacinth (Eichhornia crassipes) and water lettuce (Pistia stratiotes L.). Biores Technol 99:2495-2500

35. Chang VS, Nagwani M, Holtzapple MT (1998) Lime pretreatment of crop residues bagasse and wheat straw. Appl Biochem Biotechnol 74:135-159

36. Chang VS, Nagwani M, Kim CH, Holtzapple MT (2001) Oxidative lime pretreatment of high-lignin biomass. Appl Biochem Biotechnol 94:1-28

37. Karr WE, Holtzapple MT (1998) The multiple benefits of adding non-ionic surfactant during the enzymatic hydrolysis of corn stover. Biotechnol Bioeng 59:419-427

38. Peng HD, Li HQ, Luo H, Xu J (2013) A novel combined pretreatment of ball milling and microwave irradiation for enhancing enzymatic hydrolysis of microcrystalline cellulose. Bioresour Technol 130:81-87

39. Kim S, Holtzapple MT (2006) Effect of structural features on enzyme digestibility of corn stover. Bioresource Technol 97:583-591

40. Li L, Wenbing Z, Hongwei W, Yun Y, Fen L, Duanwei Z (2014) Relationship between crystallinity index and enzymatic hydrolysis performance of cellulose separated from aquatic and terrestrial plant materials. Bioresources 9(3):3993-4005

41. Converse AO, Kwartneg IK, Grethlein HE, Ooshima H (1989) Kinetics of thermochemical pretreatment of lignocellulosic materials. Appl Biochem Biotechnol 20(21):63-78 
42. Maeda RB, Serpa VI, Rocha RAL, Mesquita RAA, Anna LMMS, De Carlo AM, Driemeier CE, Pereira N, Polikarpov I (2011) Enzymatic hydrolysis of pretreated sugar cane baggase using Penicillium funiculosum and Trichoderma harzianum cellulases. J Process Biochem 30:5-8

43. Hu J, Arantes J, Saddler JN (2011) The enhancement of enzymatic hydrolysis of lignocellulosic substrates by the addition of accessory enzymes such as xylanase: is it an additive or synergistic effect. Biotechnol Biofuels 4:36

44. Langkilde FW, Svantesson A (1995) Identification of celluloses with Fouriertransform (FT) mid-infrared, FT-Raman and near-infrared spectrometry. J Pharm Biomed Anal 13:409

45. Marimuthu TS, Atmakuru R (2012) Isolation and characterization of cellulose nanofibers from the aquatic weed water hyacinth-Eichhornia crassipes. Carbohydr Polym 87:1701

46. Deshpande SK, Bhotmange MG, Chakrabarti T, Shastri PN (2008) Production of cellulase and xylanase by Trichoderma reesei (QM 9414 mutant), Aspergillus niger and mixed culture by solid state fermentation (SSF) of water hyacinth (Eichhornia crassipes). Ind I Chem Tech 15:449-456

47. Toyama M, Ogawa K (1977) Cellulase production of Trichoderma viride in solid and submerged culture methods. In: Ghosh TK, Ghosh TK (eds) Proc. symp. On bioconversion of cellulosic substrates into energy, chemical and microbial protein. IIT, New Delhi, India, pp 305-312

48. Kang SW, Park YS, Lee JS, Hong SI, Kim SW (2004) Production of cellulose and hemicellulases by Aspergillus niger KK2 from lignocellulosic biomass. Bioresour Technol 91:153-156

49. Polizeli MLT, Rizzati ACS, Monti R, Terenzi HF, Jorge JA, Amorin DS (2005) Xylanases from fungi: properties and industrial applications. Appl Microbiol Biotechnol 67(5):577-591

50. Mussatto SI, Teixeira JA (2010) Lignocellulose as raw material in fermentation processes. In: Méndez-Vilas A (ed) Current research, technology and education topics in applied microbiology and microbial biotechnology. Formatex Research Center, Badajoz, pp 897-907

51. Sun YC, Weu JL, Xu F, Sun RC (2011) Structure and thermal characterization of hemicelluloses isolated by organic solvents and alkaline solutions from Tamarix austromongolica. Biores Technol 102:5947

52. Arantes V, Saddler JN (2010) Access to cellulose limits the efficiency of enzymatic hydrolysis: the role of amorphogenesis. Biotechnol Biofuels 3(4):1-11

53. Preez JC, Bosch M, Prior BA (1987) Temperature profiles of growth and ethanol tolerance of xylose fermenting yeasts Candida shehatae and Pichia stipitis. Appl Microbiol Biotechnol 25:521-525

54. Mukhopadhyay S, Chatterjee NC (2010) Bioconversion of water hyacinth hydrolysate into ethanol. BioResourses 5(2):1301-1310

55. Agbogbo FK, Coward-Kelly G, Torry-Smith M, Wenger KS (2006) Fermentation of glucose/xylose mixtures using Pichia stipitis. Process Biochem 41:2333-2336

56. Gupta R, Sharma KK, Kuhad RC (2009) Separate hydrolysis and fermentation (SHF) of Prosopis juliflora, woody substrate for the production of cellulosic ethanol by Saccharomyces cerevisiae and Pichia stipitis-NCIM 3498. Bioresour Technol 100:1214-1220

57. Kuhad RC, Gupta R, Khasa YP, Singh A (2010) Bioethanol production from Lantana camara (red sage): pretreatment, saccharification and fermentation. Bioresour Technol 101:8348-8354

58. Manilal VB, Narayanan CS, Balagopalan C (1991) Cassava starch effluent treatment with concomitant SCP production. World J Microbiol Biotechnol 7:185-190

doi:10.1186/s40643-014-0027-3

Cite this article as: Pothiraj et al.: Sustaining ethanol production from lime pretreated water hyacinth biomass using mono and co-cultures of isolated fungal strains with Pichia stipitis. Bioresources and Bioprocessing 2014 1:27.

\section{Submit your manuscript to a SpringerOpen ${ }^{\odot}$ journal and benefit from:}

- Convenient online submission

- Rigorous peer review

- Immediate publication on acceptance

- Open access: articles freely available online

- High visibility within the field

- Retaining the copyright to your article

Submit your next manuscript at $\gg$ springeropen.com 